GEORGE L. PERRY

Brookings Institution

\title{
What Have We Learned about Disinflation?
}

U.S. MONETARY POLICY since 1979 has been geared to stopping inflation. It has had considerable success in doing so, but at a great cost in lost output and high unemployment, not only in the United States, but throughout the world. In Europe unemployment rose steadily from 1979 to 1982 and is expected to rise further in 1983. In the United States, unemployment rose to 10.7 percent at the trough of the recession in the fourth quarter of 1982 , more than $1 \frac{1 / 2}{2}$ points above the previous postwar record reached at the worst point of the severe 1975 recession.

The duration of economic weakness in the present disinflation period distinguishes it from previous postwar recessions even more than the amount by which unemployment rose and the level that unemployment reached. If the brief bounce-back in economic activity after mid-1980 is ignored, the recent U.S. recession lasted twelve quarters. The previous postwar record was the five-quarter recession of 1974-75. All other postwar recessions had lasted less than a year. By the end of 1983 the cumulative excess of unemployment over its 1979 level will be about 11 percentage point-years, corresponding to an estimated $\$ 700$ billion to $\$ 900$ billion of forgone GNP in today's prices.

This severe recession has been accompanied by a dramatic slowing in the rate of inflation. Table 1 summarizes several measures of inflation that reflect that slowdown, including widely used measures of actual inflation rates, which are affected by many special developments not closely associated with the underlying inflation problem, and some alternative measures of the underlying inflation rate. During the 1978-

I thank Judith D. Kleinman and Patricia J. Regan for research assistance. 


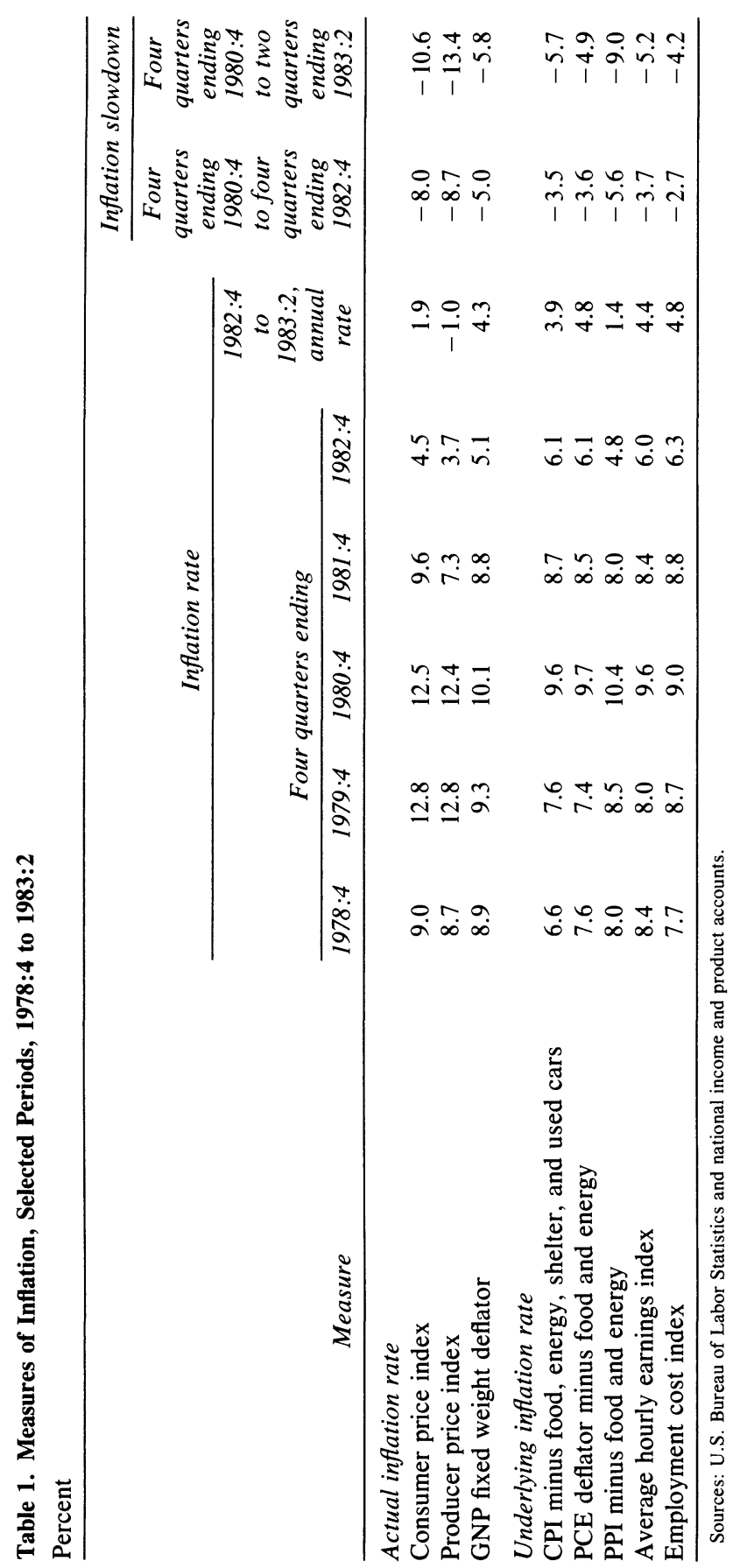


80 period a combination of price increases in food and energy (and rising interest rates as they affected the shelter component of the consumer price index) pushed the actual inflation rate to more than 10 percent, as measured by any of the principal price indexes shown in the top half of the table. In part because of the cessation or reversal of these developments, these inflation rates slowed dramatically by 1982 , and even more by the first half of 1983 .

Both the acceleration of inflation and its subsequent slowdown are greatly attenuated in the measures of the underlying inflation rate displayed in the bottom half of the table. Nonetheless, the slowdown is still substantial, amounting to 4 to $51 / 2$ percentage points between the most inflationary year, 1980, and the first half of 1983, using all measures except the volatile producer price index, which has had a much larger swing.

One important question raised by this experience is whether the disinflation that has been accomplished is more than might have been predicted on the basis of historical experience or whether it is about what would have been expected along with the huge recession that has occurred. The answer to this question, in turn, should shed some light on theoretical issues concerning how the economy works and on the options confronting policymakers. In particular, a central issue to be considered in light of the experience of the past few years is whether the relation between output and inflation will remain the same when there has been a significant change in the policy regime, such as that which occurred in the fall of 1979 .

\section{Disinflation Policy and Inflation Models}

One model of the inflation process, the wage norm hypothesis, explicitly distinguishes between the cyclical variation in inflation and an ongoing norm rate of wage increase around which the cyclical variation takes place. ${ }^{1}$ Cyclical variations in employment and inflation are jointly determined by the optimal response of firms to variations in the demand for their output. Although expectations can, in principle, alter the wage

1. George L. Perry, "Inflation in Theory and Practice," BPEA, 1:1980, pp. 207-41; and Arthur M. Okun, Prices and Quantities: A Macroeconomic Analysis (Brookings Institution, 1981). 
norm, in practice this hypothesis relates historical changes in the norm to experienced, rather than anticipated, changes in the economy.

In a wage norm equation, shifts in the norm, such as those that would arise from sustained episodes of inflation or economic slack, show up empirically as shifts in the constant term. The coefficients relating output and inflation in the short run are determined by institutional and behavioral characteristics that are largely unaffected by changes in macroeconomic policies or by changes in the wage norm itself. In empirical work, I have modeled historical norms as stable except for occasional discontinuous shifts. ${ }^{2}$ Because wage norms do not respond in a linear or systematic way to any one measure of economic performance-for instance, they would respond less to a large spurt in the CPI coming from supply shocks (1978-80) than to an equivalent increase in the CPI associated with a sustained period of very low unemployment (196669)-I preferred this procedure to more elaborate ways one might model norm shifts. It has provided an adequate, simple characterization of the past.

For the present episode, this model predicted that the policy aimed persistently at disinflation would eventually shift the wage norm downward, but only after imposing unusually great or sustained weakness in the real economy. Under these conditions, the wage norm equation would begin to exhibit forecast errors indicating that wage norms were shifting downward.

Most empirical studies of wage or price inflation have used past inflation rates, rather than the concept of wage norms, to help explain current inflation. The effect of lagged inflation in these models has generally been interpreted as representing the influence of inflationary expectations on current inflation, where these expectations are formed by an adaptive process. In such models, developments affecting inflation continue to have an influence long after they occur. And the effect of a sustained shock affecting inflation grows with the passage of time. Because the lagged inflation terms directly embody long-run and expectational effects, a sustained macroeconomic policy change is not expected to alter either the constant term or the coefficients of the equation relating output and inflation.

2. Perry, "Inflation in Theory and Practice." Charles Schultze found this characterization of norm changes explained inflation throughout the peacetime years of this century. See Charles L. Schultze, "Some Macro Foundations for Micro Theory," BPEA, 2:1981, pp. 521-76. 
New classical models differ in important respects from either of the models just described. They reject adaptive expectations as a description of how future price expectations are formed. Generally they relate these expectations to the policies that are anticipated, but that idea has never been implemented in a widely accepted way in a predictive equation. The problem is in determining what economic agents expect policy to be and what amount of inflation they think will accompany it. These models also hypothesize that markets always clear and that in doing so they incorporate expected future prices in an important way. In the pure form of such models, levels of output and employment deviate from full employment levels only because economic agents are mistaken about policy now and in the future. They interpret the very flat short-run Phillips curve estimated from historical data as a reflection of mistakes by economic agents resulting from unpredictable policies.

The central policy implication of this theory is that policy should be steady and predictable, a prescription usually interpreted as supporting monetarism. According to the theory, the mistakes of economic agents would be minimized under such a policy and the short-run relation between output and unemployment would become very steep. If the monetary policy change of 1979 was understood as a change to a steadier and more disinflationary policy regime, this theory predicted that inflation would slow more promptly and output and employment would decline less than historical equations would forecast.

A version of this theory associated primarily with William Fellner stresses the credibility of policy in a more general way. ${ }^{3}$ In this version, what matters is that policy convincingly promises it will not tolerate inflation, quite apart from precisely how policy is conducted in the short run. The credibility hypothesis also anticipated that the change in policy regime in 1979, once widely believed, would bring down inflation more promptly and with a smaller loss of output and employment than would be predicted by empirical models fit to historical periods. And furthermore, it predicts that the coefficients relating output and inflation in the short run will change under a consistent policy, making the apparent Phillips curve steeper.

As these formulations suggest, some of the important, distinctive predictions of these alternative hypotheses could be tested only after a complete cycle of disinflation and subsequent recovery, when it would

3. William Fellner, Towards a Reconstruction of Macroeconomics: Problems of Theory and Policy (American Enterprise Institute, 1976), pp. 116-18. 
be possible to observe whether the short-run relations between output and inflation had changed and whether a new inflation norm had been established. One implication of those theories that stress expectations of policy should be testable already: they promised that a clear policy commitment to disinflation would yield better results-measured as more prompt disinflation and more disinflation relative to the increase in unemployment-than models based on past experience would predict.

In this paper, I review how the actual path of inflation during the past few years compares with the path predicted by some equations fit to historical data. I also look at some disaggregated evidence about where wage disinflation has been most pronounced and how that experience compares with the past. These comparisons should indicate whether the economic performance of this period supports the claim that the change in monetary policy initiated in $\mathbf{1 9 7 9}$ has speeded up the disinflation process.

It should be noted that, if expectations are simply formed by actual experience, there is no useful distinction between the wage norm and credibility hypotheses in their predictions for the present period of disinflation. Both would then require an extended period of low actual inflation, brought about by an extended depression in economic conditions, in order to shift wage inflation downward by more than just the predicted cyclical response. There is no quantitative prediction about how large such an eventual shift down might be. If equations that rely on lagged inflation to capture long-run or expectational effects should overpredict in such a period, it would be evidence of a more favorable outcome than average past behavior would predict.

\section{Wage Inflation}

The present disinflation is first examined by looking at the behavior of wages. Because wage costs represent about two-thirds of value added in the economy, wage behavior is the main determinant of business costs and hence of the underlying trend in price inflation in most sectors of the economy.

ECONOMY-WIDE WAGES

Table 2 compares the actual increases in the average hourly earnings index with the increase predicted by two closely related wage equations 
Table 2. Actual and Predicted Wage Changes, 1979:1 to 1983:2 ${ }^{\mathrm{a}}$

Percent

\begin{tabular}{|c|c|c|c|c|c|}
\hline \multirow[b]{2}{*}{ Period } & \multirow[b]{2}{*}{$\begin{array}{l}\text { Actual } \\
\text { change }\end{array}$} & \multicolumn{2}{|c|}{ Equation 2-1 } & \multicolumn{2}{|c|}{ Equation 2-2 } \\
\hline & & $\begin{array}{l}\text { Predicted } \\
\text { change }\end{array}$ & Error & $\begin{array}{c}\text { Predicted } \\
\text { change }\end{array}$ & Error \\
\hline \multicolumn{6}{|l|}{ In sample } \\
\hline 1979:1 & 7.9 & 8.1 & -0.2 & 8.0 & -0.0 \\
\hline 2 & 6.6 & 8.4 & -1.8 & 8.5 & -1.8 \\
\hline 3 & 8.1 & 8.3 & -0.2 & 8.2 & -0.1 \\
\hline 4 & 8.0 & 8.4 & -0.4 & 8.4 & -0.5 \\
\hline 1980:1 & 9.0 & 8.3 & 0.7 & 8.3 & 0.7 \\
\hline \multicolumn{6}{|c|}{ Out of sample } \\
\hline $1980: 2$ & 9.3 & 7.8 & 1.5 & 8.0 & 1.4 \\
\hline 3 & 8.6 & 8.0 & 0.6 & 8.3 & 0.3 \\
\hline 4 & 9.8 & 7.9 & 1.9 & 8.3 & 1.5 \\
\hline 1981:1 & 9.4 & 7.9 & 1.5 & 8.2 & 1.2 \\
\hline 2 & 7.6 & 7.7 & -0.1 & 7.9 & -0.2 \\
\hline 3 & 8.1 & 7.4 & 0.7 & 7.5 & 0.6 \\
\hline 4 & 7.0 & 7.2 & -0.2 & 7.1 & -0.2 \\
\hline 1982:1 & 6.8 & 6.9 & -0.1 & 6.9 & -0.2 \\
\hline 2 & 5.8 & 6.4 & -0.6 & 6.4 & -0.5 \\
\hline 3 & 5.8 & 6.3 & -0.5 & 6.3 & -0.4 \\
\hline 4 & 4.7 & 6.0 & -1.3 & 5.9 & -1.2 \\
\hline 1983:1 & 5.2 & 5.8 & -0.6 & 5.5 & -0.3 \\
\hline 2 & 3.4 & 5.7 & -2.4 & 5.5 & -2.1 \\
\hline
\end{tabular}

Source: Estimations by the author based on George L. Perry, "Inflation in Theory and Practice," BPEA, 1:1980, pp. 207-41.

a. Wage changes are measured by the change in the log of the average hourly earnings index. Predicted wage changes, $w$, come from the following equations $(t=$ statistics in parentheses):

$$
\begin{gathered}
w=0.2+20.0 U^{-1}-8.0 U^{-1}+0.2 p_{L}+\text { dummies } \\
(4.5)(-1.7) \quad(2.7) \\
\text { standard error of estimate, } 0.8, \\
w=0.6+25.3 U^{-1}-15.1 U^{-1}+0.3 p_{L}+\text { dummies } \\
\text { (5.9) }(-3.7) \quad(4.3) \\
\text { standard error of estimate, } 0.8,
\end{gathered}
$$

where $U$ is the weighted unemployment rate, and $p_{L}$ is the change in the log of the lagged CPI. The equations differ in how historical norm shifts were modeled. See Perry, "Inflation in Theory and Practice," for further details. Equations 2-1 and 2-2 correspond, respectively, to equations 4-7 and 4-5 in that article. The sample period for both is $1954: 1$ to $1980: 1$.

I presented in my paper cited above. ${ }^{4}$ The estimated equations explicitly allowed for a norm shift after the extended demand inflation of the 1960s, and differ only in how they treat the transitional quarters of that shift statistically. Allowing for this shift sharply reduced the effect of lagged inflation on current wage changes compared to the effect estimated by

4. Perry, "Inflation in Theory and Practice," p. 228, equations 4-5 and 4-7. 
most conventional models. In the model that underlies the equations, substantial and sustained prediction errors are thus taken as evidence of a norm shift. ${ }^{5}$

Under the new policy regime, which began in 1979:4, wages at first rose somewhat faster than predicted, although the average underprediction in these first six quarters is only slightly larger than the standard error of the equations of 0.8 percent within the sample period. Still, there is no sign of exceptionally prompt disinflation in these results.

Before 1982:4 neither equation in table 2 shows evidence that wages were slowing more than predicted. Even the overpredictions from 1982:4 and 1983:1 average only 0.75 and 0.95 percent in the equations, again little different from their standard errors of 0.8 percent. Only the 3.4 percent rate of increase in average hourly earnings in 1983:2 is significantly slower than predicted by either equation. One such observation is not important. But if overpredictions of the size in that quarter are maintained, they would indicate the wage norm is shifting downward.

\section{UNION WAGES}

These recent developments in average wages have occurred in a climate of unprecedented concessions in important union wage contracts. Table 3 compares first-year wage adjustments in major union wage situations in the present disinflation with those adjustments that occurred around earlier recessions. Because of long-term contracts, these first-year adjustments, which include changes under contract reopenings, are more sensitive indicators of developments in union wages than are total effective adjustments or other averages of all union wages. The three groups of years in the table chronicle developments around the past three business cycles, starting with the last year before the downturn in the economy.

It is hard to draw inferences about the inflation process from the episode of the early 1970s because of the price controls in effect in that period. The President's Pay Board did hold down and roll back wages in 1972 and 1973 and the Dunlop committee was intensely involved in slowing wage settlements in the construction industry during the same 
Table 3. First-Year Wage Adjustments and Average Hourly Earnings around Recessions, Selected Periods, 1969 through First Half of 1983

Percent

\begin{tabular}{|c|c|c|c|c|c|c|}
\hline \multirow[b]{2}{*}{ Year } & \multicolumn{3}{|c|}{ First-year wage adjustments $^{\mathrm{a}}$} & \multicolumn{2}{|c|}{$\begin{array}{c}\text { Percent of adjustments } \\
\text { with no change or } \\
\text { decline }\end{array}$} & \multirow{2}{*}{$\begin{array}{c}\text { Average } \\
\text { hourly } \\
\text { earnings }\end{array}$} \\
\hline & $\begin{array}{l}\text { Manufac- } \\
\text { turing }\end{array}$ & $\begin{array}{c}\text { Construc- } \\
\text { tion }\end{array}$ & Other & $\begin{array}{l}\text { Manufac- } \\
\text { turing }\end{array}$ & $\begin{array}{c}\text { Construc- } \\
\text { tion }\end{array}$ & \\
\hline 1969 & 7.9 & 13.1 & 9.6 & $*$ & 3 & 6.7 \\
\hline 1970 & 8.1 & 17.6 & 14.2 & $*$ & n.a. & 6.6 \\
\hline 1971 & 10.9 & 12.6 & 12.2 & 1 & n.a. & 7.2 \\
\hline $1972^{\mathrm{b}}$ & 6.6 & 6.9 & 8.2 & 2 & 6 & 6.2 \\
\hline $1973^{\mathrm{b}}$ & 5.9 & 5.0 & 6.0 & 1 & 2 & 6.2 \\
\hline $1973^{b}$ & 5.9 & 5.0 & 6.0 & 1 & 2 & 6.2 \\
\hline 1974 & 8.7 & 11.0 & 10.2 & 1 & 1 & 8.0 \\
\hline 1975 & 9.8 & 8.0 & 11.9 & 3 & 8 & 8.4 \\
\hline 1976 & 8.9 & 6.1 & 8.6 & $*$ & 11 & 7.2 \\
\hline 1977 & 8.4 & 6.3 & 8.0 & 3 & 4 & 7.6 \\
\hline 1979 & 6.9 & 8.8 & 7.6 & $*$ & * & 8.0 \\
\hline 1980 & 7.4 & 13.6 & 9.5 & $*$ & * & 9.0 \\
\hline 1981 & 7.2 & 13.5 & 9.8 & 13 & 1 & 9.1 \\
\hline 1982 & 2.8 & 6.5 & 4.3 & 52 & 15 & 6.8 \\
\hline $\begin{array}{l}\text { 1983, first } \\
\text { half }\end{array}$ & -1.9 & 1.6 & 5.4 & 72 & 60 & $4.9^{\mathrm{c}}$ \\
\hline
\end{tabular}

Source: BLS, Current Wage Developments, various issues.

n.a. Not available.

* Less than 0.5 percent.

a. Settlements covering one thousand or more workers

b. Year of wage controls.

c. Change from one year earlier.

period. ${ }^{6}$ That strategy was an alternative to the present attempt at disinflation through monetary restraint alone. It has been criticized because it distorted relative prices in the economy and because aggregate restraint did not accompany the direct controls. Ultimately it was abandoned under the inflationary pressures of the supply shocks of 1973-74.

A cleaner comparison is available between the last two recessions. First-year union wage adjustments jumped up in 1974-75 when controls ended in an environment of double-digit inflation rates stemming from the food and energy price explosions. Thereafter, they slowed only

6. The committee chaired by John T. Dunlop was formally known as the Construction Industry Stabilization Committee. 
slightly in manufacturing and substantially outside manufacturing. By comparison, first-year wage adjustments have slowed dramatically in recent quarters, to the point of negative average adjustments in manufacturing in the first half of 1983.

Table 4. Employment Changes of Production Workers from Prerecession Year, Three Cycles, 1970 through First Half of 1983

Percent

\begin{tabular}{ccccc}
\hline $\begin{array}{c}\text { Cycle and } \\
\text { year }\end{array}$ & Total & $\begin{array}{c}\text { Durable } \\
\text { goods }\end{array}$ & $\begin{array}{c}\text { Con- } \\
\text { struc- } \\
\text { tion }\end{array}$ & $\begin{array}{c}\text { Total } \\
\text { private } \\
\text { sector }\end{array}$ \\
\cline { 2 - 4 } $1970-73$ & & & & \\
1970 & -4.9 & -6.9 & -0.7 & -0.1 \\
1971 & -8.3 & -11.4 & 2.0 & -0.1 \\
1972 & -4.9 & -6.9 & 8.1 & 3.6 \\
1973 & 0.5 & 0.9 & 13.0 & 8.3 \\
$1974-77$ & & & & \\
1974 & -1.3 & -0.8 & -3.3 & 1.2 \\
1975 & -12.1 & -13.4 & -17.5 & -2.3 \\
1976 & -8.1 & -9.3 & -17.4 & 1.3 \\
1977 & -4.7 & -4.8 & -11.3 & 5.7 \\
$1980-83$ & & & & \\
1980 & -5.7 & -7.3 & -4.0 & 0.0 \\
1981 & -6.9 & -8.9 & -8.8 & 0.9 \\
1982 & -15.1 & -19.3 & -14.6 & -1.3 \\
1983 , first half & -18.0 & -22.9 & -22.1 & -2.7 \\
\hline
\end{tabular}

Source: BLS, Employment and Earnings, various issues.

The difference between these adjustments, which cover major unions, and broader measures of economy-wide wage movements, such as the average hourly earnings index shown in the table, shows that the wage slowdown has been unusually great among major unions this time, with union wages in manufacturing and construction under especially great pressure. Indeed, the concentration of wage pressures is even greater than the wage adjustments reveal because of the composition of changes within all first-year adjustments. In 1982, 52 percent, and in the first half of 1983,72 percent, of the wage adjustments in manufacturing represented either no change or a decline in wage rates. What had been a negligible phenomenon in manufacturing industries in the past became a dominant one in this recession. In the first half of 1983 an unprecedented 60 percent of wage adjustments in the construction industry showed no change or decline. 
These unusual wage developments have corresponded with the exceptional and prolonged employment declines shown in table 4. In durable goods industries, where the most publicized wage concessions have occurred, production worker employment fell 24 percent between 1979 and the first quarter of 1983 . Over a comparable period starting in 1973, the decline was only 8 percent. Even at its low point in 1975, employment in durable goods industries was only 13 percent below its 1973 level. This correspondence of extreme wage weakness with extreme employment weakness does not support the idea that the present slowdown in economy-wide wage averages is coming from any unusual expectations about macroeconomic policy. Such policy expectations should, presumably, influence wage decisions everywhere.

\section{Forecasting Prices}

An additional look at the present disinflation is provided by examining price rather than wage forecasts. Prices are more volatile than wages and, partly because of this, may reveal changes in the economy's response to recent policy that are not yet apparent in wage statistics. To examine this possibility the disinflation period is next examined using the equation for the fixed-weight GNP price deflator presented previously by Gordon and King. ${ }^{7}$ This equation utilizes a distributed lag of past inflation rates, rather than explicit norm shifts, to capture long-run and expectational effects.

The main source of instability in the Gordon-King equation appears to come from three variables capturing the effects of certain relative prices, including the prices of foreign traded goods: the relative prices of food and energy, the relative price of total imports, and the effective exchange rate. In view of this instability, three forms of the equation are used, with each estimated for the original data period, 1954:2 to 1980:4 (shown in footnote a of table 5). In addition to the independent variables shown, each equation includes variables for the minimum wage rate, the effective social security tax rate, and dummy variables for the period of Nixon price controls. These had little or no effect in the forecast period and are omitted for simplicity.

Equation 5-1 is the previously published Gordon-King equation, which is reestimated here with the recently revised national accounts

7. Robert J. Gordon and Stephen R. King, "The Output Cost of Disinflation in Traditional and Vector Autoregressive Models," BPEA, 1:1982, pp. 205-42. 
Table 5. Predicted and Actual Inflation Rates, Fixed Weight GNP Deflator, Selected Periods, 1980:4 through 1983:2

Percent

\begin{tabular}{lccc}
\hline & $1980: 4-1981: 4$ & $1981: 4-1982: 4$ & $1982: 4-1983: 2$ \\
\hline Actual change & 8.8 & 5.1 & 3.9 \\
Forecast & & & \\
$\quad$ Equation 5-1 & 6.2 & 4.2 & 3.1 \\
Equation 5-2 & 7.4 & 4.3 & 2.8 \\
$\quad$ Equation 5-3 & 8.4 & 5.6 & 4.5 \\
Errors (actual minus & & & \\
$\quad$ forecast) & & 0.9 & 0.8 \\
Equation 5-1 & 2.6 & 0.8 & 1.1 \\
Equation 5-2 & 1.4 & -0.5 & -0.6 \\
Equation 5-3 & 0.4 & & \\
\hline
\end{tabular}

Source: Estimations provided by Robert J. Gordon, as described in the text, based on Robert J. Gordon and Stephen R. King, "The Output Cost of Disinflation in Traditional and Vector Autoregressive Models," BPEA, 1:1982, pp. 205-42.

a. The coefficients on the main independent variables in the price equations are shown below; all are logs or changes in logs and all are significant at the 5 percent level. For simplicity, some additional variables of little or no importance in the forecast period are not shown. See the first equation in table 2 of Gordon and King, p. 218, for the detailed specifications. The dependent variable in each case is the change in the log of the fixed weight GNP price deflator.

\begin{tabular}{|c|c|c|c|c|c|c|c|c|}
\hline \multirow[b]{3}{*}{$\begin{array}{c}\text { Equa- } \\
\text { tion }\end{array}$} & \multicolumn{7}{|c|}{ Independent variables } & \multirow{3}{*}{$\begin{array}{l}\text { Stan- } \\
\text { dard } \\
\text { error } \\
\text { of esti- } \\
\text { mation }\end{array}$} \\
\hline & \multicolumn{2}{|c|}{ Lagged inflation } & \multirow[b]{2}{*}{$\begin{array}{c}\text { Output } \\
\text { ratio }\end{array}$} & \multirow{2}{*}{$\begin{array}{l}\text { Produc- } \\
\text { tivity } \\
\text { growth }\end{array}$} & \multirow{2}{*}{$\begin{array}{c}\text { Food } \\
\text { and } \\
\text { energy } \\
\text { prices }\end{array}$} & \multirow[b]{2}{*}{$\begin{array}{l}\text { Import } \\
\text { prices }\end{array}$} & \multirow{2}{*}{$\begin{array}{c}E x- \\
\text { change } \\
\text { rate }\end{array}$} & \\
\hline & $\begin{array}{l}1954: 2- \\
1966: 4\end{array}$ & $\begin{array}{l}1967: 1- \\
1980: 4\end{array}$ & & & & & & \\
\hline $5-1$ & 0.92 & 1.04 & 0.36 & -0.15 & 0.44 & 0.06 & -0.13 & 0.803 \\
\hline $5-2$ & 0.97 & 1.08 & 0.35 & -0.23 & 0.10 & 0.10 & -0.08 & 0.862 \\
\hline $5-3$ & 0.94 & 1.10 & 0.36 & -0.21 & 0.21 & 0.08 & $\ldots$ & 0.857 \\
\hline
\end{tabular}

data. Equation 5-2 uses the exchange rate over the 1961-80 period rather than just the 1975-80 period used in 5-1. Equation 5-3 drops the exchange rate variable altogether and relies on food and energy prices and total import prices to capture foreign trade price effects.

The actual inflation rates in the postsample period and the dynamic forecasts from the three equations are compared in table 5 . As shown in the wage equation of table 2 , prices rise faster than predicted in the earliest period shown, in this case 1981. Both 5-1 and 5-2 reveal that the inflation slowdown has been, if anything, disappointingly small throughout. Only equation 5-3, which omits the exchange rate and relies on the variables for relative import prices and food and energy prices to capture the effects of foreign prices, predicts more inflation than occurred, and its overpredictions are very small and do not occur until 1982. Thus in the Gordon-King price equation there is no evidence supporting the 
Table 6. Predicted Effect of Individual Variables on Inflation Rate, Selected Periods, 1980:4 through 1983:2

Percentage points

\begin{tabular}{lcrcc}
\hline \multicolumn{1}{c}{ Variable } & & $1980: 4-$ & $1981: 4-$ & $1982: 4-$ \\
\hline Output ratio & $5-1$ & -1.4 & -3.1 & -3.8 \\
& $5-2$ & -1.5 & -3.2 & -4.0 \\
Productivity growth & $5-3$ & -1.5 & -3.3 & -4.1 \\
& $5-1$ & 0.1 & -0.2 & -0.3 \\
Food and energy prices & $5-2$ & 0.1 & -0.3 & -0.3 \\
& $5-3$ & 0.1 & -0.3 & -0.3 \\
Import prices & $5-1$ & -0.3 & -0.2 & -0.9 \\
& $5-2$ & -0.1 & 0.0 & -0.3 \\
& $5-3$ & -0.1 & -0.1 & -0.5 \\
Exchange rate & $5-1$ & 0.0 & -0.6 & -0.8 \\
& $5-2$ & -0.1 & -1.0 & -1.2 \\
& $5-3$ & 0.0 & -0.9 & -1.2 \\
Addendum & $5-1$ & -1.6 & -1.3 & -0.6 \\
All relative price & $5-2$ & -0.7 & -1.0 & -1.3 \\
variables & $5-3$ & $\ldots$ & $\ldots$ & $\ldots$ \\
& & & & \\
& $5-1$ & -1.8 & -2.2 & -2.3 \\
& $5-2$ & -0.8 & -2.1 & -2.9 \\
& $5-3$ & -0.2 & -1.0 & -1.6 \\
\hline
\end{tabular}

Source: Same as table 5 .

credibility hypothesis in connection with the present policy of disinflation or pointing to a downward shift in inflation norms greater than historical equations would predict.

Table 6 identifies the contribution of the individual independent variables to the slowdown in inflation predicted by the Gordon equations. The table shows how much inflation should have changed as a result of the independent variables taking on their actual values since 1979:4 rather than the unemployment rate staying constant at 6 percent, productivity rising at its trend rate, and all relative prices remaining unchanged. The estimates shown allow for both the direct effect on inflation of the change in each variable, and its effect acting through the lagged inflation rate which is endogenous in the projection period. By the first half of 1983 the shortfall of output below trend accounted for a slowdown in inflation of about 4 percentage points in each of the 
equations. This is the minimum effect that can be attributed directly to the disinflationary policy.

The effects of the three relative price variables account for an additional 2.9 to 1.6 percentage points of disinflation, depending on which equation is used. If these effects too are credited to the policy of the period, that policy has reduced the inflation rate by an estimated 6.9 to 5.6 percentage points, producing the forecast errors shown in table 5 . Food and energy prices had already slowed during 1980 . So almost all these relative price effects come from import prices and, when it is used, the exchange rate variable. Thus part of these anti-inflation benefits come at the expense of corresponding pro-inflationary pressures on the countries whose dollar exchange rates declined. And they are reversible if the exchange rate moves back toward its level in earlier years.

\section{The Inflation Process and Policy}

Monetary policymakers since 1979 have shown historically unusual determination to fight inflation and willingness to raise unemployment in the process. Although many issues remain, this experience has shed light on some questions about the inflationary process and the costs of disinflation. Developments have certainly not supported the central promise of some classical models that once steady disinflationary policies are in place, disinflation will take place with little output loss. The disinflation that occurred was not exceptionally prompt, and when wages finally did slow by unusually large amounts in some manufacturing industries and construction, that development was accompanied by unusually large declines in employment.

\section{CREDIBILITY VERSUS AUSTERITY}

No measure exists of what private decisionmakers thought about policy aims in this period. Because of this, one could argue that the promised benefits of credible disinflationary policy have not been realized because the credibility of anti-inflation policy has never been established. However, the Federal Reserve has certainly worked hard to establish its credibility. It persisted in its restrictive policies, implemented through money supply targets, long after its predecessors would 
have turned to fighting recession. And in the spring of 1983 it already moved to restrain the expansion only months after it began. The commitment to fighting inflation has been more clear and credible than ever before in the postwar era.

Ultimately determination should pay off. The evidence about the slowdown in inflation that has finally occurred in 1983 is still unclear. But in my mind, the biggest surprise will be if inflation does not slow by more than the cyclical wage equations predict. Wage norms have shifted upward in the past under sustained periods of prosperity and cyclical inflation, and they should shift downward now under the opposite, sustained condition. In the current period it is hard to distinguish this prediction from those of the credibility hypothesis if the latter require the actual experience of an extended slump to establish policy credibility. But in this case, it has no distinctive implications for policy. Only if there is an important difference between credibility and austerity is the former of any special interest.

The predictions from the Gordon-King price equation (5-3) must be interpreted differently from either of these views. That equation does not hypothesize norm shifts, but does continuously shift the short-run Phillips curve through an accelerationist lagged dependent variable. One interpretation of the equation's modest underpredictions of inflation in recent quarters-in specifications that use the full array of relative price variables, including the exchange rate-is that the high elasticity of lagged inflation exaggerates the speed and size of the reaction of actual inflation to its recent past. Alternatively, if that specification is correct, disinflation in the recent period must be interpreted as disappointingly slow. In any case, the prediction errors are not large and lend no support to the view that credible policy has speeded up the disinflation process and made it less costly.

THE LONGER RUN

Some important messages for theory and policy may not be clear until and unless policy allows a sustained recovery in economic activity. Presumably, the implicit hope in the present disinflation policy is not only that inflation might be sharply reduced, if not ended, but also that high employment might then be resumed without returning to the underlying inflation rates of the past fifteen years. All the inflation models 
are at least partially optimistic on this point, though for different underlying reasons. But they do offer somewhat different prospects for output and inflation in the longer run. The new classical models predict that, under the appropriate policy regime, the cyclical relation between inflation and unemployment will change and maintained full employment will be compatible with price stability. The absence thus far of the disinflation predicted by these models casts doubt on this prediction as well.

The inflation-output relation may, in fact, not be sensitive to the policy regime. As the historical studies by Gordon and by Schultze have shown, these coefficients have been surprisingly invariant to the differing policy regimes that have prevailed during this century. ${ }^{8}$ If it turns out that inflation cannot be controlled sufficiently without continually holding back expansion, then other programs for dealing more directly with inflation may have to be put back on the policy agenda.

\section{RECENT POLICY}

Whatever lessons emerge for the longer run, the decision to turn to a severely restrictive monetary policy in 1979 must be viewed against the economic risks that then existed. Energy prices were rising very rapidly in 1979 and 1980. Inflationary psychology had apparently spread to other volatile markets, and wages were accelerating. Even with the turn to restrictive policies and the recession that ensued, wages rose faster than predicted in 1980. Without that policy shift, faster inflation would almost surely have become imbedded in the economy, and very likely a still faster and more stubborn wage norm and underlying inflation rate would have resulted.

Once that acceleration was interrupted, as it was by 1981 , the costs and benefits of continuing the restrictive monetary policy became more debatable. Reasonable observers can and do differ about how long and how much to depress the economy in order to reduce inflation. The results presented here suggest that we have gotten about what would have been predicted from past experience, just more of it because this recession was longer and deeper than others.

8. Robert J. Gordon, "A Consistent Characterization of a Near-Century of Price Behavior," American Economic Review, vol. 70 (May 1980, Papers and Proceedings, 1979), pp. 243-49; and Charles L. Schultze, "Some Macro Foundations for Micro Theory." 